\title{
Multilevel Industrial Policy: Methodological Basis of System Approach to Its Formation and Implementation
}

\author{
Alexander P. Zhabin ${ }^{1}$, Elena V. Volkodavova ${ }^{1}$ \&Tatyana V. Goryacheva ${ }^{2}$ \\ ${ }^{1}$ Samara State University of Economics, Samara, Russia \\ ${ }^{2}$ Yuri Gagarin State Technical University of Saratov, Saratov, Russia \\ Correspondence: Elena V. Volkodavova, Samara State University of Economics, Sovetskoi Armii str. 141, \\ Samara, 443090, Russia.
}

Received: October 31, 2014 Accepted: December 20, 2014 Online Published: March 16, 2015

doi:10.5539/ass.v11n7p176 URL: http://dx.doi.org/10.5539/ass.v11n7p176

\begin{abstract}
The article illustrates the theoretical and methodological aspects of forming and implementing multilevel industrial policy, demonstrates the directions of forming the system of managing the multilevel industrial policy. System approach is suggested to distinguish six sub-systems in the internal structure of the examined system: target oriented, supportive, managing, managed, functional, communicative. The homogeneous character of these subsystems is defined. The scientific analysis of system reveals its philosophy, logic, activity character, methods, principals, temporary structure of activity, technologies of forming and implementing the multilevel industrial policy.
\end{abstract}

Keywords: industrial policy, multilevel management system, economic integration, methods, forms, models, principals of policy formation and implementation

\section{The Problem}

The necessity of forming and implementing industrial policy in national (economy has been constantly doubted by some scientists and economists, this question is open for discussion (Lapochkina, 2013). This could be explained by the fact that in a number of cases industrial policy implies government interference in the activity of market institutions; giving advantages to some branches at the cost of others; setting up imbalance on the commodity market and economy in general. Besides, the preliminary stage of conducting the target-oriented industrial policy in a short-term and sometimes in a long-term period cause additional costs. But we should also notice another aspect of the process - countries that recently managed to increase the level of their economy development and change from developing to the developed ones, accomplished this due to carrying out successful industrial policy (Japan, Finland, Malaysia, China, South Korea, Taiwan) (Kondratiev, 2006; European Commission, 2002; Drobyshevskiy, 2010).

Of course the first stages of implementing industrial policy are carried out with the dominating economic interests. The government acts as a direct partner of big industries and promote their interests; at this time it takes into account the interests of society at the minimum rate (Rodrik, 2005). The main target of industrial policy is to provide the national security in all aspects, social aspects are taken into account only in the critical spheres of society life: employment guarantee, healthcare, food provision. The main aspect is made for the strong defense industry, increasing the profit from taxation, export duties and etc.

However already on the second stage the basic social guarantees are balanced. On this stage in the process of forming and implementing industrial policy the negative influence on the social sphere (healthcare, education, unemployment) and scientific environment are considered. Similarly the adverse effect of social sphere on the industrial development is taken into consideration. It is on this stage when industrial policy should become the fully legitimate element of general economic policy of the country, and in many cases its basis.

The final stage should provide equality, and in some segments - domination of social interests on the economic ones. The opinion of society plays the key role while forming and implementing industrial policy. The meaning of social aspects (ecology, ethics, culture) is increasing and becomes even equal to the economic ones. Social sphere in modern industrial policy is considered as the object and participant of the process of developing national industry. But this process could be implemented only on the basis of correct and efficient management. 
The necessity to develop industrial policy cannot be doubted, its formation and implementation should be carried out on the basis of using managerial approaches, methods, tools, and their implementation will contribute to developing industrial policy as the basis of economic policy of the country.

\section{System Approach to Forming and Implementing Industrial Policy}

Industrial policy refers to the class of social and economic systems where the man sets tasks for every system element. It is quite difficult to manage such systems. We have a relatively small experience of managing such systems, theoretical and methodological apparatus is being developed. If in the situation of Soviet economy industry development was considered as a closed system with strict boarders and relatively independent from external environment, nowadays in the situation of world integration it is impossible to overlook the influence of competition, informatization and many other factors influencing the formation and implementation of industrial policy.

Industrial policy is not isolated from other elements of national regulation and influence on country economy, it is a logical and efficient part of social and economic strategy of economy subjects development on all the levels of integration processes: from the supranational level to the level of enterprise. Therefore it is targeted to achieve the balance between the goals of economic, social and in some cases political country development.

The peculiarities of projecting the internal structure of management system are widely represented in modern economic literature. For example, in the monograph "Managing the product competitiveness" (1995) R. Fatkhutdinov represented the internal structure as the aggregate of the following subsystems: scientific rationale of system, target-oriented sub-system, supportive sub-system, managed sub-system, managing sub-system (Fatkhutdinov, 1995).

Using this approach, but with the addition of another classification characteristics (homogeneous elements of the system), we distinguish the following management system components of multilevel industrial policy:

1. Target-oriented sub-system ("exit");

2. Supportive ("entrance");

3. Managing (subject);

4. Managed (object);

5. Functional;

6. Communicative.

We should notice that the nature of the elements of every sub-system is not homogeneous, it can be technical (the complex of some types of technical equipment, special means); economic (the aggregate of economic and financial processes, operations and links), technologic (the set of rules and standards, determining the sequence of operations in the process of the certain type of activity and managing them; organizational (the aggregate of management structure, instructions, regulations and other normative documentations that determine the rational use of resources); social (the aggregate of social relations that appear in the process of joint activity of society groups) (Table 1).

Such system element as "scientific rationale" (distinguished by R. Fatkhutdinov) is the methodological basis of the system that includes the principals, forms, methods, means of elements interaction in the process of forming and implementing industrial policy. The idea of the great importance of providing the scientific rationale for management system development is in the fact that the efficiency of mental work is higher than the efficiency of physical work (Drucker, 2004) and it is better to invest on this stage than lose on the stage of production and exploitation. In reality it is not the system element, but the component making the ground for the interaction of management system components.

On "entrance" the system possesses resource components coming from the external environment: financial, personnel, informational, material, production-technical, technological, organizational-structural, spatial, entrepreneurial ability. The main task of management subject is the provision of high quality "entrance". "The exit" of system is the competitive products, services, new technologies, innovations and etc.

The components of scientific rationale of system functioning should provide the efficiency and competitiveness of separate system components. Their not high efficiency influences the negative characteristics of national economy development: low resource efficiency of national production (twice or three times lower than in European countries and Japan); due to the living standards Russia occupies the 61 place (the results of 2013). Due to the Ministry of Economic Development though the share of innovation production has grown from $4.4 \%$ in 2000 to $7.8 \%$ in 2012 (Sokolov, 2013), the share of technological innovation production in the export of industrial sphere has decreased from $12.5 \%$ in 2003 to $4.9 \%$ in 2012 (Russian statistical yearbook, 2013). 
Table 1 . The elements of multilevel system of industrial policy management

\begin{tabular}{|c|c|c|}
\hline Subsystem name & Subsystem content & $\begin{array}{l}\text { The characteristics of } \\
\text { element homogeneity }\end{array}$ \\
\hline \multirow{4}{*}{$\begin{array}{l}\text { Target-oriented } \\
\text { sub-system } \\
\text { ("exit") }\end{array}$} & $\begin{array}{l}\text { Increasing the competitiveness of national industry, industrial complex, } \\
\text { economic subjects, commodities, services }\end{array}$ & Economic \\
\hline & $\begin{array}{l}\text { Entering and expanding the external and internal markets of products and } \\
\text { services supply }\end{array}$ & Economic \\
\hline & Increasing the efficiency and profitability of industrial production & Economic \\
\hline & The increase of population welfare & Social \\
\hline \multirow{5}{*}{$\begin{array}{l}\text { Supportive } \\
\text { ("entrance") }\end{array}$} & Investment support & Economic \\
\hline & Methodical support & $\begin{array}{l}\text { Organizational and } \\
\text { technological }\end{array}$ \\
\hline & Legislative and regulatory support & $\begin{array}{l}\text { Organizational and } \\
\text { technological }\end{array}$ \\
\hline & Resource support & Technical social economic \\
\hline & Information support & Technological economic \\
\hline \multirow{7}{*}{$\begin{array}{l}\text { Managing } \\
\text { (“subject”) }\end{array}$} & The bodies of managing the economic integration institutions (Customs & Economic \\
\hline & Union, WTO, Eurasian Economic Community, BRICS and etc) & organizational \\
\hline & RF President and Government & - \\
\hline & RF Chamber of commerce and industry & - \\
\hline & $\begin{array}{l}\text { Governors of RF subjects; } \\
\text { Government of RF subjects }\end{array}$ & - \\
\hline & Chambers of commerce and industry in the regions & - \\
\hline & Management of economic subjects & - \\
\hline \multirow{5}{*}{$\begin{array}{l}\text { Managed } \\
\text { (“object”) }\end{array}$} & National economy & Economic social \\
\hline & Branches & $\begin{array}{l}\text { Economic Technical } \\
\text { Organizational Social }\end{array}$ \\
\hline & Territorial industrial complexes, industrial and innovation systems & $\begin{array}{c}\text { Economic Technical } \\
\text { Organizational }\end{array}$ \\
\hline & Clusters & $\begin{array}{l}\text { Economic Technical } \\
\text { Organizational } \\
\text { Economic Technological }\end{array}$ \\
\hline & Economic subjects & $\begin{array}{c}\text { Technical Organizational } \\
\text { Social }\end{array}$ \\
\hline \multirow{4}{*}{ Functional } & $\begin{array}{l}\text { Production, services } \\
\text { Planning the methods, means of implementing the aims of industrial } \\
\text { policy }\end{array}$ & $\begin{array}{l}\text { Economic Social } \\
\text { Economic Technical } \\
\text { Organizational }\end{array}$ \\
\hline & Organizing the process of managing the multilevel industrial policy & $\begin{array}{c}\text { Economic Technological } \\
\text { Organizational }\end{array}$ \\
\hline & $\begin{array}{l}\text { Coordinating the activity of industrial policy subjects in the process of } \\
\text { managing them } \\
\text { Stimulating the activity of implementing the efficient industrial policy }\end{array}$ & $\begin{array}{l}\text { Economic Technological } \\
\text { Technical Organizational } \\
\text { Economic Social }\end{array}$ \\
\hline & Control of the development and implementing industrial policy & $\begin{array}{l}\text { Economic Technological } \\
\text { Social }\end{array}$ \\
\hline Communicative & Communication plan & $\begin{array}{l}\text { Technological } \\
\text { Organizational }\end{array}$ \\
\hline
\end{tabular}

While in the USSR the share of enterprises accomplishing innovation activity was about $50 \%$, at present time not more than $9.1 \%$ of enterprises accomplish technological innovations in Russia. In the countries of Eastern Europe this index is about $25-30 \%$, in Western Europe - more than $40-50 \%$ - due to the research of Higher School of Economics and Rosstat. The share of new innovative products, works and services in Russia was $0.8 \%$ in Russia in 2012, though in Poland it was 4.5\%, in Germany - 3.3\%, in Portugal - 8.6\%.

In general scientific rationale of management system is reflected in the approaches to its creation and should contain the following components:

1. Basic elements:

- Philosophy of forming and implementing industrial policy that supposes the definition of general base, boarders of implementation and policy opportunities, the relation of objective and subjective origin, distinguishing 
regulations and causality, all this makes it possible to examine the nature of the process of forming and implementing industrial policy on all the hierarchical levels;

Modern industrial policy should be based on understanding the new place of every country in the changing world. The principal peculiarities of modern industrial policy should be taken into account on both federal, regional and municipal levels (Tatarkin, 2008);

- The logic of examining and creating the process is based on the conceptual hierarchy of forming and implementing industrial policy on the chain "integrative institution-government-region-enterprise", at the same time the reverse direction of creating the hierarchical chain "enterprise-region - government-integrative institution" is possible;

- System analysis and systemology makes it possible to represent industrial policy as a multilevel management system for the adequate reflection of its objective reality.

\section{Activity characteristics:}

- The peculiarities of the process of forming and implementing industrial policy are different on every level, for example on the level of integrative institutions it is a complex combination of national and supranational mechanisms, and not only the supranational mechanism as it is. On this level the supranational mechanism is formed as the phenomenon of international regulation of industrial policy in the countries - participants of integrative processes. The construction and support of the elements functioning in this mechanism is important on all the levels (social, political, economic, institutional, legislative and the level of decision-making on the issues of accomplishing and implementing industrial policy on the subject-economic level) of cross-country system of participating countries interaction in integrative institutions. It is necessary to notice that any supranational mechanism supposes following the system of rules and procedures that are defined by the order of international alliance functioning. This order is negotiated on the international level between the participating countries, its dominance over the national institutions and interests should be negotiated in advance and supported by various international agreements and documents. The degree of national control is also defined on the initial stage of supranational mechanism functioning. As a rule, national interests of participating countries are put higher than the supranational that is why from this point of view supranational mechanism has a limited character.

In this situation the interconnection and interdependence of national economics of the countries participating in integrative institutions are increasing. Firstly, it relates to less developed countries actively participating in international differentiation of labour in integrative institutions. The consistency of implementing industrial policy on the supranational and national levels makes it possible to achieve the high level of participating countries integration.

Defining the basis of implementing industrial policy as the system of its development on all the levels should be based on distinguishing the ways, mechanisms of its creation, as well as the subjects and objects of this system.

- Industrial policy tools are different and various, but among the main ones should be distinguished - customs policy (customs and tariff regulation); decreasing the administrative barriers; defense of property rights including the intellectual ones; competitive and antimonopoly policy; the system of supporting export and investment activity; stimulating innovation activity; tax regulation; technical regulation; grants, credits and guarantees, Federal target programs.

While implementing industrial policy the countries were using mixed tools: traditional (granting, tax stimulating, direct support of educational sphere); specific (government support of commercializing scientific work-outs, creating specific funds and etc.).

- the principals of forming and implementing industrial policy are defined in the following way: coordination and unification of national industrial policy with industrial politicians of the countries of international economic integration; industry restructuring on the basis of choosing the priority science-based production; economy efficiency and profitability thanks to the development of infrastructure, education, resource base mobility; equal rights of common economic space subjects in accomplishing and developing industrial policy; consolidation of activities on forming and developing the national industrial policy; transparency of scientific and research work results, accomplishing joint scientific and research work and fundamental research; personnel mobility, their geographical and professional rotation; harmonizing the unity of technical standards and regulations of the countries of economic integration; indicative character of evaluating the results of industrial policy implementation on national and supranational levels; joint responsibility for accomplishing and results of the unified industrial policy; 
- Conditions of providing the possibility of forming and implementing the multilevel industrial policy, the main ones are: establishing the social state; economic and financial globalization; establishing the nets without limits (national boarders) in the sphere of telecommunication, transport, infrastructure. At the same time it is necessary to mention the conditions that we did not have for implementing industrial policy in Russian federation and the absence of which prevent the economic growth of Russian industrial production and the development of industrial policy: financial restrictions (misbalance and structural deformation of financial system of the country; the lack of turnover means for the enterprise; high level of credit debts on taxes); low internal consumer demand; low development of commodity markets infrastructure; low development of market institutes (the absence of adequate market of factoring, leasing, trust services); low investment and innovational activity; amortization, climate and territorial restrictions; the problem of labour resources (decreasing the number of high-quality personnel in high technology and science based branches); price limits and disproportion; external economic problems.

\section{Logic structure of the activity:}

- The subjects of industrial policy is the state of modern type, including government apparatus; private business and integrated business groups, chamber of trade and commerce; civil society in general and scientific society in particular;

- The object of modern industrial policy is separate branches, production, corporations, as well as producers of goods and services (industrial enterprises, some entrepreneurs and etc.)

- The subject of the process of forming and implementing industrial policy is industrial, trade and supply activity that is accomplished on all the levels of hierarchy;

- Forms of industrial policy: hard and soft (Rodrik, 2004), but on the modern development stage many countries have reached the understanding of the necessity of implementing soft industrial policy;

- Industrial policy models can be implemented in the following way: export-oriented (supporting production targeted on production export by developing and supporting competitive export branches); import substitution model (the strategy of providing internal market on the basis of developing national production). Import substitution supposes the introduction of protectionist policy and support of strong national currency, it is effective to use it in the period of applying economic sanctions to the countries); innovation model (contributes to support of scientific and technological potential of the country, its competitiveness on the international arena; stimulates the development of educational institutions and provide high quality personnel to the economy; contributes to creating work places in the country and provide internal demand; supports stable and strong position of national currency; focused on production development with high added value of production in machinery complex, machine-tool manufacturing and professional equipment).

- Methods. We will use cross classification based on two parameters for characterizing the methods of industrial policy: due to content and character of interaction that will make it possible to show the character of the used methods of industrial policy: supportive and regulating character (most widely used in Russian economy) and stimulating and forming (recommended by the authors of research in the situation of modern economy of developing integrative economic processes (See Figure 1).

- The results of implementing the multilevel industrial policy: economic (increasing the efficiency of economic systems of all the levels, their competitiveness, profitability, efficiency, GDP; increasing the sales of some companies); scientific-technical (developing all types of innovations; new competitive production, technologies, services; samples); social (the growth of budget efficiency; growth of enterprise employees well-being); ecological.

\section{Temporary structure of activity: phases, stages, milestones.}

The process of accomplishing the activity on forming and implementing industrial policy is considered in the situation of a certain time sequence due to the phases, stages, milestones, when this sequence is common for all activity types. The finish of the development cycle of multilevel industrial policy is defined by three phases (Novikov et al., 2004):

- Projecting phase. Result - the model of multilevel management system and its implementation plan;

- Technological phase. Result - implementing the program on creating the system of managing the multilevel industrial policy;

- Reflective phase. Result - evaluating the efficiency of the work of multilevel industrial policy management system, making the decision about the necessity of its future correction, or "restart" in a new context. 


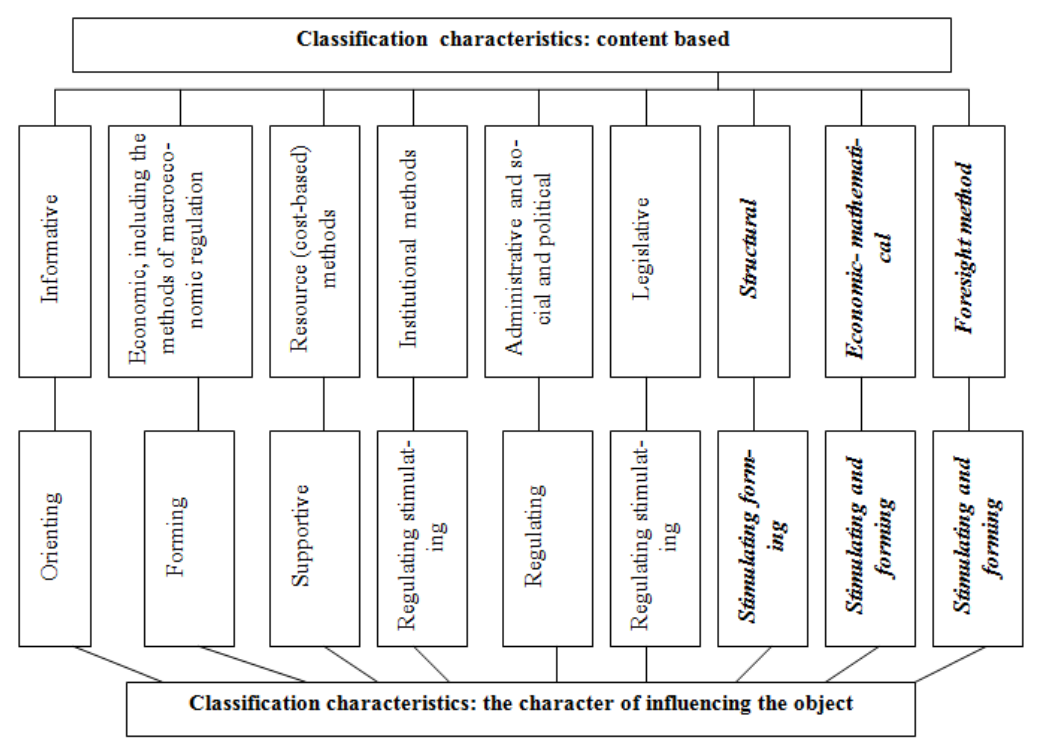

In italics we have the methods suggested by the authors in classification system

Figure 1. Classification of industrial policy methods

The technology of accomplishing works on forming and implementing the management system of multilevel industrial policy includes the means, tools, methods, ways and looks as the system of legal, economic, organizational and other measures contributing to forming the competitive industrial complex, providing its efficient functioning.

\section{Conclusions}

When managing the similar system, the planned result is achieved with the deliberate influence on its entrance parameters, the feedback will make it possible for the system to react independently on the warnings from external environment and get used to them. The highest level of managing similar system is its self-management. Self-management should be achieved at the cost of system elements interaction, by getting used to the changes of external environment, implementing the opportunities of external environment, the ability to change the internal structure and the condition in order to achieve the more efficient result, and also the ability for self-study (Savelyeva, 2012-2013; Lisovsky, 2014; Valetov, 2014; Vazhenina \& Vazhenin, 2014; Novikov, Novikov, \& Hmaruk, 2014, 2010).

The results of this research make it possible to admit that in modern conditions of economic integration the formation and implementation of multilevel industrial policy occupies one of the leading places in increasing the efficiency of national industry. This determines the necessity to consider the management system of industrial policy as the integrated structure with the elements: entrance, exit, supportive, target oriented, functional, communicative subsystems.

Taking into account complexity and multifunctionality of similar system formation and the realization of industrial policy is recommended to be enabled on the basis of the following approaches:

- To develop taking into account a factor of internal uniformity of an element and factors of a megasreda;

- To carry out the analysis and monitoring of the formation process of industrial policy based on a complex assessment of its realization level and to control how this policy is managed according to the tendencies of the changing indicators included in assessment/evaluation system;

- To apply industrial policy to an enterprise using the unity of innovative (priority of realization), commodity and structural, and investment elements according to organizational and functional structure of business processes of the enterprise;

- To develop and apply the concept industrial policy in regional territories by means of a program method in the form of industrial and innovative system that will allow to connect the formation of industrial policy with its realization at all levels. 


\section{References}

An Integrated Industrial Policy for the Globalisation Era Putting Competitiveness and Sustainability at Centre Stage SEC (2010). 1272, COM (2010) 614 final.

Drobyshevskiy, S. M. (2010). International experience of anti-crisis policy (pp. 15-20). M.: Delo.

Druker, P. F. (2012). Effective manager (exclusive gift edition).

Fatkhutdinov, R. A. (2009). Management of Goods Competitiveness. Moscow Joint-stock company.

Heilmann, S. (2011). Mao's Invisible Hand: The Political Foundations of Adaptive Governance in China (p. 320) Cambridge: Harvard University Press.

Hmaruk, K. P. (2014). Minister of the industry, business and trade of Perm Krai, "Regional industrial policy: cluster approach" the Magazine Industrial policy in the Russian Federation No. 1-3.

Kondratyev, V. (2008). State and Corporations of Global Competitiveness Strategy. Electronic magazine "International Processes", 3(18), September-December.

Lapochkina, L. V. (2013). Forming the regional industrial policy in Europe. Journal Management in Russia and abroad, 3, 34-38.

Lisovsky S. M. (2014). Minister of the industry and power industry of the Saratov region, "Development of innovative potential of an industrial complex in the Saratov region" the Magazine Industrial policy in the Russian Federation No. 1-3.

Novikov, A. M., \& Novikov, D. A. (2010). Educational project (methodology of educational activity) (p. 280). M.: Librok.

Russian statistical yearbook. (2013). Moscow, Rosstat.

Savelyeva, M. V. (2012). Influence of Regions Engines of Growth on the Development of Other Regions. Public Administration: Scientific and Political Journal, 2(76), 46-49.

Savelyeva, M. V. (2013). The Development Management of the Competitive Advantages of Regions Engines of Growth. Moscow: MAKS-Press.

Sokolov, A. (2013). Imitation of innovations: Russia is losing even the developing countries. Retrieved July 20, 2014, from http://www.top.rbc.ru/economics/17/10/2013/882656.shtml

Tatarkin, A. I. (2008). Industrial policy as the basis of system modernization of Russian economy. Journal Economy and management: Russian statistical Journal, 2, 10.

The Eu's growth strategy (p. 32). (2010). European Comission, Brussels.

Valetov, A. I. (2014a). Development of Investment in the Economy of Moscow. Problems of the Theory and Practice of Management, 8, 46-51.

Valetov, A. I. (2014b). Development of the Exhibition, Fair and Congress Activity as a Factor of Competitiveness Region (on the Example of Moscow). Regional Economics: Theory and Practice, 30(357), $18-22$.

Valetov, A. I. (2014c). The development of the city of Moscow as a global Exhibition Center. Public Administration: Scientific and Political Journal, 3(89), 39-41.

Vazhenina, I. S., \& Vazhenin, S. G. (2014). Competitive Objects and Advantages, the Image and Reputation of Territories: Sociological and Marketing Analysis. Journal of Marketing in Russia and Abroad, 1, 86-96.

\section{Copyrights}

Copyright for this article is retained by the author(s), with first publication rights granted to the journal.

This is an open-access article distributed under the terms and conditions of the Creative Commons Attribution license (http://creativecommons.org/licenses/by/3.0/). 